\title{
Absence and Presence: Top of the Pops and the demand for music videos in the 1960s
}

\section{Justin Smith}

\section{De Montfort University}

\begin{abstract}
Whilst there is a surprising critical consensus underpinning the myth that British music video began in the mid-1970s with Queen's video for 'Bohemian Rhapsody', few scholars have pursued Mundy's (1999) lead in locating its origins a decade earlier. Although the relationship between film and the popular song has a much longer history, this article seeks to establish that the international success of British beat groups in the first half of the 1960s encouraged television broadcasters to target the youth audience with new shows that presented their idols performing their latest hits (which normally meant miming to recorded playback). In the UK, from 1964, the BBC's Top of the Pops created an enduring format specifically harnessed to popular music chart rankings. The argument follows that this format created a demand for the top British artists' regular studio presence which their busy touring schedules could seldom accommodate; American artists achieving British pop chart success rarely appeared on the show in person. This frequent absence then, coupled with the desire by broadcasters elsewhere in Europe and America to present popular British acts, created a demand for pre-recorded or filmed inserts to be produced and shown in lieu of artists' appearance. Drawing on records held at the BBC's Written Archives and elsewhere, and interviews with a number of 1960s music video directors, this article evidences TV's demand-driver and illustrates how the 'pop promo', in the hands of some, became a creative enterprise which exceeded television's requirement to cover for an artist's studio absence.
\end{abstract}


Key Words: music video, Top of the Pops, Ed Sullivan, Beat-Club, Shindig!, Ready, Steady, Go!, pop promo, British invasion, miming, 1960s

\author{
Th[e] growing use of promotional clips in the mid-1960s, not just on Top \\ of the Pops but on other television shows eager to reflect and exploit \\ chart popularity, represents a significant moment in the visual economy \\ of popular music and clearly anticipates the development of music video \\ from the mid-1970s onwards (Mundy 1999: 206).
}

\title{
Introduction
}

There is a shared fascination with the conditions whereby new cultural forms come into being - their pre-history. What we now recognize as the music video had disparate origins which are bound up with the historical relations between cinema and popular music and, from the mid-1950s, television's response to the rapid expansion of the pop music industry (see Hill 1991, Mundy 1999, Donnelly 2007, Inglis 2010, Glynn 2013, Evans 2017).

The musical biopic and the pop star vehicle, which were the major manifestations of cinema's engagement with nascent rock ' $n$ ' roll, were also contemporaneous with the emergence of a range of short-form phenomena - including video juke-box novelties the 'soundie', the Snader, Scopitone and Cinebox (see Austerlitz 2007 and Herzog 2007), and the beginning of television's exploitation of popular music (see Hill 1991, Frith 2002, Coates 2007 and 2013). Thus, by 1960, the visualisation of popular musical performance already had a host of manifestations that distinguished it from the diegetic parameters of the classical film musical (see Romney and Wootton 1995, James 2017). From a musicological rather than a 
television history perspective, Simon Frith (2002) identifies two major areas of impact that television, from the 1950s, had 'on the mediation of rock and the formation of the modern pop/rock aesthetic': the visual presentation of the pop act, and its promotional function (2002: 277). ${ }^{i}$ In these ways, television assumed and extended pop radio's primary role into the visual realm.

Drawing on this established context, archival materials from the BBC Written Archives, Caversham, the Musicians' Union Archive, University of Stirling, and the Peter Whitehead Archive at De Montfort University, and original interviews conducted with some of the earliest music video directors, this article will show how television's intervention made a significant difference to what Mundy calls the 'visual economy' of popular music in creating demand for music video. The commercial logic of the music video originated within this convention as one form of substitute for studio performance - as a presence to cover an absence. This article argues that music video emerged in the UK in the 1960s as a direct, if limited, response to the configuration of a new economic relationship between television and the record industry, the international popularity of British beat groups, and the chart success of many American artists in Britain.

\section{Top of the Pops}

Within a year of its launch on 1 January 1964, the BBC's Top of the Pops (1964-2006) established its unassailable position as British television's premier pop show, eclipsing Associated-Rediffusion's Ready, Steady, Go! (1963-1966) which ended in December 1966, by which time the beat group phenomenon had already reached its climax. Unlike RSG!, which arguably captured the contemporary spirit of popular music culture and distilled it far more successfully during its three-year run, TOTP revivified the chart show format (derived from American radio) that had begun a decade earlier with Hit Parade (BBC 1952, 1955-6), 
and perfected it. The then BBC Head of Variety, Bill Cotton Jr., recalls the changes in the pop charts that made the new format feasible:

In the past, most of the pop hits had been American, so we hadn't been able to mount a Top Twenty TV show in Britain, but times were changing ... Thanks largely to the Beatles, there had been an amazing renaissance in pop culture and by now most the Top Twenty records sold in Britain were made by British acts. How about a weekly television programme featuring the Top Twenty? (Cotton 2000: 105)

Whilst Hit Parade had drawn on the original chart information supplied (from 1952) by the New Musical Express, by 1960 the rival pop paper Record Mirror (1954-91) had its own weekly chart. They both produced Top 30 listings based on retail data from a small sample of London record stores. But in 1959, the trade paper Record Retailer was launched as a monthly subscription publication for members of the Gramophone Record Retailers Association and began producing its own independent charts by format (singles, EPs, LPs) extending its singles sales data to a Top 50. In 1960, the paper began weekly circulation. Although the data-gathering initially drew on only a small sample of thirty retailers contacted by phone, they operated the same 'points system' as the popular music press for calibrating data (to avoid bunching) and introduced postal returns from early in 1964, drawing on retailer distribution lists supplied by record companies EMI and Decca to compile a master list of 100 outlets based in London, Manchester and Liverpool. ${ }^{2}$

By the time Top of the Pops launched then, the chart 'business' was well underway. TOTP, in the early years, assembled a Top 30 derived from the weekly BBC radio show Pick of the Pops (1955-1972) which had introduced its Top 20 chart run-down in 1957 (compiled from a synthesis of press data from the NME, Melody Maker, Record Retailer and Disc 
listings). The early presenters of the 25 -minute show (extended to 30 minutes in October 1964 and 35 minutes from September 1965) emphasised continuity with Pick of the Pops: Alan Freeman and David Jacobs (who also helmed Juke Box Jury, BBC 1959-67, 1979, 1989-90); they were joined by DJs Pete Murray and Jimmy Savile.

The programme was originally based in Manchester (in a converted chapel in Dickenson Road, Rusholme), and went out live on Wednesday evenings at 6.35 with artists miming to their records in front of an audience of local youngsters. ${ }^{3}$ From September of its first year it was re-scheduled to Thursday evenings (where it remained) in order to give producers Johnnie Stewart and Stanley Dorfman more time to arrange the acts (following receipt of the chart data every Tuesday afternoon). Its success and immediacy (rapidly establishing its promotional status with the record industry) depended on meeting the demands of the simple, but challenging rules it set itself. The show would only feature Top 30 climbers (single releases going up the charts), and would always include that week's No.1. This had two implications. Firstly, it relied upon prediction, which boosted the nefarious practices of the notorious record pluggers (see Negus 1992) and the promotional role of the show itself. Secondly, it relied upon studio appearances by the selected artists (and crucially those who occupied the No.1 spot). In respect of the latter, this presented TOTP with an immediate problem especially in respect of American acts. And, as the 'British invasion' took hold, this was a reciprocal challenge for broadcasters of pop shows in the USA and continental Europe. It is one of the contentions of this article that the development of the music video during this period was initially determined by this absence of artists, as filmed inserts began to be employed by pop TV shows on a regular basis in lieu of studio appearance.

\section{In Absentia}


Of necessity, TOTP quickly established some straightforward solutions to the problem of artists' unavailability for live recording. The simplest one was pre-recording a mimed studio performance to be seamlessly inserted into the show as if the artist was present. ${ }^{4}$ These Ampex tape recordings were usually made on a Wednesday. As an internal memo about resource needs from Johnnie Stewart makes clear: 'This often applies ... to American artistes on a few days' promotion visit to England, or to English artistes on tour or leaving for America or elsewhere abroad. A small set is necessary in this studio'. ${ }^{5}$ Where artists were available during the day on Thursday (but not for the show's broadcast in the evening), Ampex recordings also took place in the TOTP studio in Manchester (later in London) beforehand. Famously, The Beatles, who only ever appeared once on the show in person, frequently adopted this approach, and many other top acts whose busy touring schedules prevented attendance did the same. ${ }^{6}$

As well as Ampex recordings, filmed inserts were also used on occasion from the earliest days of TOTP. These were either filmed by the BBC or, more rarely, were supplied by the artists' management or record labels. The BBC used film as a matter of course for the programme's opening title sequence, thus telecine facilities were installed as standard. But also, as Stewart reported:

Other filmed inserts are sometimes used, mute or with sound according to circumstances. Most film is $35 \mathrm{~mm}$ but occasionally only $16 \mathrm{~mm}$ is available. Sometimes, also, film clips are used which necessitate rectifying the distortion ...... ... of a wide-screen appearance ... Almost all filmed inserts are run in sync on studio B.P. [back projection], provided there is time to obtain a second copy. In such cases sound is taken from Telecine. ${ }^{7}$

Specially filmed inserts had to be completed at breakneck speed: 
Filming often has to be done at very short notice, so that first the disc has to be transferred quickly to film track, then, if a crew can be mustered, processing and editing facilities are likely to be required within hours of the film being shot. Ideally, three copies of such film are needed - one cutting copy, a second to run on Telecine and a third to show on B.P. ${ }^{8}$

An early example was a film shot of Roy Orbison in the roof garden of Derry and Toms department store in London's Kensington to accompany 'Oh Pretty Woman' (Simpson 2002: 22, Humphries and Blacknell 2014: 27). Directed by Stan Dorfman, it was shot on 19 October 1964, broadcast on TOTP on 22 and 29 October, and 12 and 19 November. However, this rather functional approach to covering visually the chart records TOTP featured in lieu of artists' appearance, was something that frustrated some of the emerging British beat groups.

One of the earliest documented examples of a purpose-made music video is provided by Alex Wharton (aka Murray), co-manager and producer for the Moody Blues, whose first UK chart success was with the Bessie Banks ballad 'Go Now'. ${ }^{9}$ The single was released on 13 November 1964 and began to climb the charts in early December. But the band was scheduled to go on a UK tour with Chuck Berry on 8 January 1965 and so Johnnie Stewart, routinely, requested that they pre-record a studio performance. However, neither Murray, nor the band's road manager, Steve Christian, were entirely satisfied with the standard BBC staged recording and Murray vowed to try to do better. Steve Christian had worked in the film industry, most recently as $3^{\text {rd }}$ Assistant Director on The Mind Benders (1963) produced by Michael Relph and directed by Basil Dearden. He knew the ropes, had a union card and was capable of putting together an experienced film crew, that included cinematographer Denys Coop. The video established a simple shot of a lone, platinum-blonde female figure 
(played by Murray's girlfriend Annette Compton) walking across barren heathland, that was overlaid with a 'head-and-shoulders' group performance (dressed in black) captured with dramatic spot-lighting and employing a travelling matte technique. It was shot on 29 December 1964 (35mm, b/w) on location at Barn Hill, Kingsbury, Middlesex and, in the afternoon, at the Marquee Club in London. It was financed and directed by Alex Murray as a Murray-Christian production, ${ }^{10}$ with an Assistant Director credit going to Christian. As the single rose through the charts the Moody Blues mimed to it in a TOTP studio appearance on New Year's Eve 1964 before setting off on tour. The video was then shown on 14 and 21 January 1965, by which time 'Go Now' had reached No. 1. As Wharton told me, 'I like to think the promo did its job'. ${ }^{11}$ This is the first documented example of the commercial/aesthetic function of music video in Britain, and is indicative of the do-ityourself approach that some enterprising artists pursued in experimenting with promotional films. It is interesting that, in this case, it was a fledging act (with a good deal of managerial autonomy) rather than an established group, that broke new ground.

\section{The Proto Promo Business}

While TOTP frequently featured in-house 'specially filmed' inserts, this work was also increasingly farmed out to independent sources. Director Tom Taylor's Caravel Films, based in Slough, were regular suppliers to TOTP (Simpson 2002: 22), starting with an animation made for the Rolling Stones' 'It's All Over Now' (shown 5 August 1964). Peter Clifton, employed on an occasional basis by TOTP as a film editor, shot a music video for Procol Harum's 'A Whiter Shade of Pale' among the ruins of Witley Court in Worcestershire (Humphries and Blacknell 2014: 25), and sold his footage of Jimi Hendrix's performance of 'Hey Joe' from the Saville Theatre concert on 29 January 1967 to the BBC for $£ 200 .{ }^{12}$ In July 
1966 John Crome, who went on to make TV commercials for Eyeline and directed music videos for Manfred Mann (in a deal with their manager Gerry Bron), was commissioned by the $\mathrm{BBC}$ as an Assistant Producer to work on three film inserts for TOTP for a fee of $£ 50$ per insert. ${ }^{13}$ He also made film inserts for the short-lived BBC pop magazine show $A$ Whole Scene Going (1966). Freelance film-maker Peter Whitehead was also a regular contributor to TOTP through his connection with Andrew Loog Oldham's Immediate Records label, selling the BBC promos for the Rolling Stones' 'Have You Seen Your Mother, Baby (Standing In The Shadow)?' (shown 22 September 1966), The Dubliners' 'Seven Drunken Nights' (shown 13 April 1967), The Shadows' 'Maroc 7' (shown 13 April 1967) and 'Bombay Duck' (shown 11 May 1967), the Beach Boys' 'Then I Kissed Her' (shown 18 May 1967), The Monkees' 'Alternate Title' (shown 6 July 1967), and the Small Faces' 'Itchycoo Park' (shown 13 July 1967) at a going rate of $£ 180$ each. $^{14}$

The business model of these transactions was rudimentary and variable. On the BBC's side it was driven by the need to cover the absence of artists whose latest record was climbing the charts or had reached No.1, and this was often unpredictable and invariably lastminute. But in these cases the BBC would either shoot its own footage or commission a filmmaker to do so, in which cases the BBC paid for production and retained the rights. Savvy film-makers who recognized the demand for filmed performances (music videos) of major acts from TV stations in Britain and abroad, also increasingly did deals with an artist's management or their record label independently. Peter Whitehead, for example, would negotiate deals with managers based on the cost of production (anything between $£ 200$ and $£ 400$ per video) usually paid on a fifty-fifty advance/completion basis, and supply additional finished prints (either as part of the initial deal or as required thereafter) for anything between $£ 10$ and $£ 30$ per print (depending on the artist and their requirements). Artists’ management would then negotiate supply deals with TV companies or Whitehead would deal with them 
directly. He retained the rights in his films (though not of course, in the sound recordings).

Figure 4 illustrates the extent of such purpose-made promos shown on TOTP during the 1960s. It is compiled primarily by cross-referencing the BBC's Programmes-AsBroadcast (PAB) records with the published research of Seaton with Down (2007). ${ }^{15}$

Record labels and artists' management were generally reticent about the cost/benefits of short-film promotion in a music market where, when TOTP began, the feature-length pop star vehicle was still the apogee of film presentation (see Glynn 2013). Indeed, it is no coincidence that the most internationally successful British artists in 1965, The Beatles and the Dave Clark Five, already had film experience before they ventured into producing their own promotional shorts.

Despite the retrospective critical approval lavished upon the 'Can't Buy Me Love' sequence in A Hard Day's Night (Lester, 1964) and the 'Ticket To Ride' sequence in Help! (Lester, 1965), ${ }^{16}$ The Beatles' first bespoke music videos (directed by Joe McGrath at Twickenham Studios on 23-24 November 1965) are visually bland affairs by comparison. These static sound-stage performances, which covered all their UK singles of 1965 including 'Ticket to Ride' and the forthcoming double A-side 'Day Tripper'/'We Can Work It Out', were leavened only by the comic misappropriation of some theatrical props, despite the best efforts of RSG! designer Nichoas Ferguson. But presumably Brian Epstein considered the results suitably palatable for the widest possible international circulation (for which purpose they were transferred to $16 \mathrm{~mm}$ film). In truth, imaginatively they are little better than the routine TOTP BBC studio pre-recordings and were, like those, recorded on 2" Intertel tape, though in colour. Recalling the shoot in 1981, Joe McGrath acknowledged as much and blamed Epstein: 'He wanted to get as many videos as we could done in the short time we had, so we had to shoot everything indoors. We were limited more or less to watching The Beatles 
play their instruments, which is what Brian said the audience wanted'. ${ }^{17}$ Yet, as Tony Bramwell remembered, when EMI's accounts department discovered the production had cost $£ 750$ they raised objections about the extent of the planned distribution (Bramwell 2005: 161). It appears that, even when it came to The Beatles, the attitude of record labels to video promotion was parsimonious in the extreme.

Similarly, the following year when Michael Lindsay-Hogg was commissioned, on the strength of his innovative work on RSG!, to direct promotional films for The Beatles' 'Paperback Writer' and its B-side 'Rain' (UK release 10 June 1966), he pitched 'a story video about someone working in a newspaper office who in his spare time was trying to write a paperback novel' (Lindsay-Hogg 2011: 116). ${ }^{18}$ However, despite the support that this narrative concept received from The Beatles themselves, when filming dates were scheduled Brian Epstein indicated that he wanted to keep it simple: nothing 'unusual, just a video of the boys performing' (ibid). What transpired was a day of studio recording both tracks (on Intertel VTR) at Abbey Road (19 May1966), followed by a day (20 May) on location (on $35 \mathrm{~mm}$ colour film) in the grounds of Chiswick House, West London.

The Chiswick House films were shown domestically on TOTP ('Paperback Writer' on the 2 and 23 June, and 'Rain' on 9 June), while the studio colour video recordings were broadcast on the Ed Sullivan Show (CBS, 1948-71) in the USA on 5 June, and in b/w on Beat-Club (EDF/ARD, 1965-72) on 18 June (see Figs. 2.1, 2.3 and 2.4). 'Paperback Writer' entered the charts at No. 2 and was No. 1 for the following two weeks. At a time when The Beatles had ceased touring, it is arguable that more attention was devoted from this time forth to capturing new releases on film, yet the reticence of Brian Epstein, once again, limited the creative possibilities on this occasion. It was not until Peter Goldmann was enlisted, at the end of 1966, to shoot promotional films for 'Penny Lane' and 'Strawberry Fields Forever', that convincing attempts were made to convey visually something of the psychedelic 
expression of those Lennon and McCartney musical memories of the Liverpool of their childhood. Ironically, Epstein was quoted as saying they were the 'Best clips of this type I have ever seen, really great..., 19

Dave Clark was quicker to recognize the potential of promotional films and less constrained by management than The Beatles initially were. With the assistance of the film historian and TV producer David Gill - then working as an editor in Outside Broadcast at Associated-Rediffusion and a card-carrying member of the ACTT - the DC5's first video for 'Come Home' (May 1965) was shot in the chamber of horrors at Madame Tussauds and involved Dave Clark in a brief assignation with a Swedish actress, which was considered sufficiently lurid to be rejected by the BBC. On safer ground, a promo for 'Try Too Hard' was filmed by Dave Clark at Lansdowne Studios in Holland Park and shown on the $E d$ Sullivan Show on 24 April 1966 (see Fig. 2.1). This was followed by a more ambitious project shot (like the previous films on $35 \mathrm{~mm}$ and in colour) over two weeks in July 1966, of the band water-skiing on Batchworth Lake, Rickmansworth, horse-riding at Camber Sands and driving a fleet of E-type Jaguars (made iconic by Catch Us If You Can) at a disused wartime airfield. This material was edited by David Gill and then used in various guises. Initially the water-skiing sequence was shown on the Ed Sullivan Show to accompany the US single release 'Nineteen Days' (1966) (see Fig. 2.1). The following year it was re-used (without permission) by Beat-Club for two DC5 singles 'You Got What It Takes' (1967) and 'Tabatha Twitchit' (1967) (see Fig. 2.3). But its real purpose (after 'Nineteen Days') was as an extended 12-minute promotional short Hits in Action (1966) (that incorporated the studio performance of 'Try Too Hard') which was distributed internationally in cinemas in front of the latest James Bond film, You Only Live Twice (1967). Just as The Beatles had created Subafilms Ltd in 1965, Dave Clark established Big Five Films to produce this material. Acutely conscious of the potential of film as a publicity medium, Dave Clark's inspiration for 
this 'action-adventure' location footage came from commercial advertising, 'the Guards cigarette ads and the Cadbury's Milk Tray man'. ${ }^{20}$ Although his aim was to promote the group's youthful, stylish energy rather than creating specific film sequences to express the mood of particular songs, his significant innovation was to shoot extended non-performance material on location deliberately for promotional purposes (and to show it in cinemas as well as on pop TV). In the hands of Dave Clark then, 'wild film', where the use of documentary, stock footage or 'home movies' legitimized the idea of showing a performer doing things other than performing the music it accompanied, became a purposeful strategy rather than simply reportage. It can also be viewed as a pragmatic response to the difficulties of miming to playback in straight performance videos, which was outlawed by the Musicians' Union from August $1966 .^{21}$

\section{'Wild footage', American friends and the continental connection}

The use of 'stock footage' or 'wild footage' shown to accompanying playback was an all too frequent remedy to cover the absence of artists required for TOTP. This was a rather unsatisfactory - though sometimes surprisingly innovative - solution, since it lacked any element of song-specific performance. In one of its more outlandish assignments a BBC crew was responsible for 'filming 11 members of the British Sub-Aqua Club at a London swimming pool' for The Beatles' 'Yellow Submarine', and persuading 'a BBC scene-shifter (who also happened to be an actor)' to pose in a cemetery for still photographs as 'Father Mackenzie' for 'Eleanor Rigby' (Lewisohn 1992: 225) first broadcast on TOTP on 25 August 1966. Previously, 'Ticket To Ride' had also been accompanied by speeded-up footage of the London to Brighton train ride on 13 May 1965 (Humphries and Blacknell 2014: 17). Philip Jenkinson, who established himself as the Debonair Film Agency (and went on to front the BBC's Film Night (1968-73)), was a regular supplier of stock footage via his work for the 
distributor Contemporary Films. On 29 December 1967, Jenkinson received payment of $£ 60$ for one and half minutes' footage to cover an extract from The Who's 'I Can See For Miles' and for one and a quarter minutes' to cover an extract from The Jimi Hendrix Experience's 'Purple Haze', both broadcast in the Christmas Day special show. ${ }^{22}$

Understandably, the British chart success of American artists posed a particular challenge for TOTP's producers. A letter Stewart wrote to Frank Sinatra's representative Mickey Rudin on 13 May 1966 illustrates the necessarily speculative approach this often entailed:

When American artists are not available, we film them in America ('wild' or miming to the record) and fly the footage to London. A number of artists like Tony Bennett, the Righteous Brothers, Roy Orbison, Sonny and Cher, the Beach Boys etc. etc. have been featured on the show in this way.

I am wondering, therefore, if by any chance you know of any 'wild' footage of Frank Sinatra (16mm or $35 \mathrm{~mm})$ which could be edited to, and shown against, his recording of 'Strangers in the Night', as this disc is rocketing in to the best-sellers over here. It does not need to tie up exactly with the song, but can be in any situation i.e. film of him playing golf, driving a car, walking around his home or garden etc. This kind of presentation does at least enable the viewers to see an artist although it is impossible for him actually to appear on the show.

This enquiry is illustrative of what had become standard practice for American artists required for TOTP. It also reveals Stewart's somewhat utilitarian attitude to finding film material in lieu of artists' appearance: it didn't need 'to tie up exactly with the song'. 
From November 1965, as the first wave of British beat group success reached its climax and rival American pop acts began making new inroads into the UK charts, Johnnie Stewart established a regular US supply line with Hollywood producer James Fitzpatrick. Jim Fitzpatrick set up his own production service The American Film Foundation to supply 'colour motion pictures of recording artists for distribution to television stations in major markets in Europe and the USA' ${ }^{23}$ By July 1967 he had sold to TOTP 'films featuring James Brown, The Four Seasons, Gene Clark, The Chiffons, The Four Tops, The Supremes, Roy Orbison, Gene Pitney, Ike and Tina Turner, Herb Alpert, Sonny and Cher, The Beach Boys, Gene Barry, Roy Head, The Mamas and The Papas, Wilson Pickett, Roger Miller, Percy Sledge, The Turtles, Petula Clark, [and] The Young Rascals'. ${ }^{24}$ Stewart regularly paid in excess of \$2000 per film and urged Fitzpatrick to 'do a bit of business for me and try and get a few dollars off the cost of any pictures you make as my accounts are rapidly beginning to look a bit sick!'. ${ }^{25}$ On 16 August 1967 Fitzpatrick responded, reporting that he had employed 'a full-time man, George Van Noy, to explore and develop the market for these films here in the States':

For openers he sent letters to every television station in every major market... And he found that the programs that use film have become accustomed to paying zero. ...

Then, hoping we could induce the artists to pick up the tab, we tried another gambit. We sent a form letter ... to every record producer and promoter in the United States...like 460! I was (and am) hoping we could get some nibbles from some of the better groups, make a film for them, and then send it along to you (no charge) when it made your chart. ${ }^{26}$ 
Fitzpatrick's efforts to develop a viable business model for proto music videos are revealing in a market where television broadcasters and record labels alike were reluctant to pay for these promotional films. Arguably, TOTP's commitment to screen every No.1 record meant that it had to pay a price which, in turn, stimulated the production of filmed material on both sides of the Atlantic.

It is clear from their regular correspondence, that Fitzpatrick delivered a mixed bag of material for TOTP, combining what performance footage of artists he could obtain with 'wild' coverage sufficient for the duration of the single in question, depending on the timeframe (which was usually urgent) and the artists' (and their managements') level of cooperation. But it satisfied Stewart's need to cover the song one way or another. Despite TOTP being uniquely driven by chart performance, there was equally strong demand, in the wake of the 'British invasion', to cover the appearances of the top UK artists on US and continental European TV shows.

Broadcast listings for the Ed Sullivan Show in the 1960s reveal that both The Beatles and the Dave Clark Five (the British pop acts who appeared most frequently) supplied a number of clips on tape and film (see Fig. 2.1), while Shindig! (produced by the ex-pat Jack Good for the ABC network, 1964-6) frequently represented British acts in absentia on tapes acquired from Top of the Pops or Ready, Steady, Go!, or with band-made video clips (see Fig. 2.2). The premier continental European pop show, West German Radio Bremen's Beat-Club, adopted a similar policy and showcased some videos made by British artists that had been banned by the BBC as unsuitable for Top of the Pops, such as Peter Whitehead's 'political' film for the Rolling Stones' 'We Love You' (1967). ${ }^{27}$ Similarly, Whitehead's innovative video for Eric Burdon and the Animals' 'When I Was Young' (1967), which combined an intense studio performance with archive reconnaissance footage of Battle of Britain dogfights, was sold to Dutch television for $£ 45$. $^{28}$ And the Kinks' self-made, social comment 
video for 'Dead End Street' (1966), also rejected by TOTP, was subsequently shown on the French TV show Bouton Rouge (ORTF 1967-8) in early 1967, and Belgian television's Vibrato on 8 March 1967 (Hinman 2004: 92). The same year, Beat-Club was also able to present Peter Goldmann's videos of 'Strawberry Fields Forever', and 'Penny Lane' in colour (see Fig. 2.3). ${ }^{29}$ Whilst both Beat-Club and Shindig! were committed to the default format of presenting artists 'live' in their studios (although mostly only singing live to record playback), they also both produced one-off shows that were composed entirely of prerecorded performances on tape and film. ${ }^{30}$

Although this overview does not constitute a comprehensive survey of broadcast output, analysis of available data is sufficient to support the contention that, by 1966-7, television pop music shows in the UK, the USA and continental Europe between them generated significant demand for the circulation of pre-recorded performance footage, the production of purpose-made music videos, and the supply of other film material to cover record playback.

\section{Conclusion}

Simon Frith (1996: 225) has made claims for the relative autonomy afforded by music videos 'because they enable musicians (or their record companies) to translate their performing ideals into televisual terms directly, without having to be mediated by the established norms of TV entertainment'. Yet elsewhere, he has acknowledged that, historically, 'one of the reasons why the conventions of rock performance are different from those of previous pop forms is because of the effects of television' (Frith 2002: 284-5). Although there has not been space here to address performance style, this article has shown how pop television's use of film footage or pre-recorded performances to accompany playback of chart singles in the absence of the artists concerned, was heavily mediated in this period (not only by the 
broadcasters themselves but by pressure from the Musicians' Union to suppress miming to commercial recordings). ${ }^{31}$ But, following Frith, it has also illustrated examples of challenges to those broadcast norms on the part of some artists, which gave rise to purpose-made films produced either by the acts themselves or by emergent film-makers.

The handful of directors who made these films had mixed pedigree. Some, like John Crome, had trained in the film industry and worked in advertising; others like Michael Lindsay-Hogg, Peter Clifton and Peter Goldmann honed their craft in television; Derek Nice (who directed Pink Floyd's first video for 'Arnold Layne') and Peter Whitehead were artiststurned-film-makers, and Vic Singh (who made a one-off promo for 'I'm A Man' by the Spencer Davis Group) was a fashion photographer. At this point it was primarily the bands themselves and their management who embraced the idea of the promo film, at first for expediency, and later for more creative reasons. Sometimes, as in the case of the Moody Blues, the Kinks and the Dave Clark Five, the artists and/or their managers made their own promotional films, often with striking results. The formal innovations of music videos in the 1960s must be dealt with elsewhere, but TOTP's rejection of some of the more radical examples and the wide international circulation of others, is indicative of the significance of this work, beyond its marketing imperative, as a creative extension of the music.

There is a critical consensus (to which Mundy subscribes) that music video proper emerged in the UK in the mid-1970s, and this periodisation is underpinned by a popular mythology that Queen's video for 'Bohemian Rhapsody' (1975) was the foundational example. This originary myth has been supported by some leading scholars of popular music: Keith Negus calls it 'the first conscious use of music video to promote a pop single' (Negus 1992: 93). Yet, as Mundy recognized, and this article has demonstrated, it was developments in the visual economy of popular music in the 1960s that established the commercial aesthetic of music video. 
Interestingly, with some notable exceptions (eg Mick Rock’s work with David Bowie) music video's development stalled during the early 1970s, in part because of television's rather conservative response to popular music, and in part because popular music itself fragmented and diversified in ways which made television (always only a utility medium for the transmission of pop) less important. It would take a new generation of artists and a revivification of pop music itself to engender the MTV phenomenon of the 1980s when the music video really came of age. But what this analysis of the 1960s reveals is that, as in the 1980s, music video innovation was predicated on television's response to a wave of international popularity of British acts which can be seen as intimately linked, as Lee Yoong Hon (2013) has shown, to the notion of 'invasion'. It was television that created a demand for the presence of artists which, in their absence, film fulfilled.

\section{Notes}

\footnotetext{
' For more on how early pop TV influenced performance style, see Lindelof (2007).
}

${ }^{2}$ https://www.ukmix.org/forums/viewtopic.php?t=26131 
${ }^{3}$ None the less, as TOTP's popularity grew - rising from 5.31 million in its first year to almost 20 million by the end of 1965 (Simpson 2002: 18) - attracting the top acts to Manchester was not as challenging as the BBC had at first feared. And, unlike RSG!, 'there was never any pretence about artists miming' on TOTP (Simpson 2002: 15). Indeed, the centrality of disc playback to the show was emphasized visually, in the early years, by the presence of Samantha Juste who sat at a turntable and placed the stylus on a spinning record at the cue for each song. This reinforcement of the show's (unacknowledged) promotional role (in selling hit records) could not have been clearer. Indeed, in previewing the show at its inception the Radio Times explained that: 'The performers whose songs are popular in the charts will mime to their discs, a departure from standard BBC policy. The idea is to replicate the sound of the popular track. No two performances are the same, but this performance is the one that made it a hit' (Humphries and Blacknell 2014: 5). See also note 20 below.

${ }^{4}$ Another useful innovation towards the end of 1964 was the introduction of a resident dance troupe to perform a routine in the studio to the backing track of an absent artist. The first was called the Go-Jos who became a regular feature of the show; they were replaced in 1968 by Pan's People.

${ }^{5}$ Internal memo from Johnnie Stewart, "'Top of the Pops" - London - July/September 1965', BBC Written Archives, Caversham.

${ }^{6}$ The Beatles' only appearance in the TOTP studio was on 16 June 1966 when they performed their new single 'Paperback Writer' and its 'B' side 'Rain', which went to No.1 a week later. The Beatles' first pre-recorded performance on TOTP was 'Can't Buy Me Love'. It was taped on 19 March 1964 and broadcast on 25 March, 1, 8,15 and 22 April during the single's rapid ascent and three-week No. 1 spot occupancy.

7 Internal memo from Johnnie Stewart, "'Top of the Pops" - London - July/September 1965', BBC Written

Archives, Caversham.

${ }^{8}$ Ibid.

${ }^{9}$ Alex Wharton had been an actor and singer in the late 1950s, before becoming an A\&R man at Decca (the Moody Blues' label) before forming the production and management company Ridgepride.

${ }^{10}$ According to Wharton, Ridgepride was in financial difficulties and so he funded the video production with a hastily arranged loan of $£ 700$ from Lord Peregrine Eliot, one of the partners in The Beatles lucrative merchandising companies, Stramsact and Seltaeb.

${ }^{11}$ Alex Wharton, email correspondence with the author, 4 February 2016.

12 Peter Clifton quoted by Karl Quinn, 'Easybeats film 46 years on? Too easy', Sydney Morning Herald, 22 May 2013 (NP). The original 'A Whiter Shade of Pale' video (shot in colour on 35mm) combined footage of the group's performance at the Saville Theatre, supporting Jimi Hendrix, on 4 June 1967, with location work at Witley Court, but was rejected by Johnnie Stewart because it contained inserts of newsreel footage of the Vietnam War. An alternative (less polished) promo was shot at various locations in central London and sold to Scopitone for worldwide distribution; Henry Scott-Irvine (2012), Procol Harum: The Ghosts Of A Whiter Shade of Pale, London: Omnibus Press, p. 892 (Kindle edition). Clifton went on to direct a video for the Rolling Stones' '2000 Light Years From Home' which was shown on Beat-Club on 9 March 1968 and on TOTP on 28 December that year; curiously, this track was the B-side of the US-only single release 'She's A Rainbow' for which Michael Lindsay-Hogg directed a video; Martin Elliott (2012), The Rolling Stones Complete Recording Sessions, 1962-2012 (London: Cherry Red Books), pp. 88 and 90.

${ }^{13}$ Internal memo from Leonard Michell, Light Entertainment Organiser (Variety) Television, 22 July 1966, BBC Written Archives, Caversham.

${ }^{14}$ The broadcast dates for this works come from the BBC Programmes As Broadcast (PAB) records at the Written Archives, Caversham. The authorial attribution and commercial terms come from contracts and correspondence held in the Peter Whitehead Archive at De Montfort University.

${ }^{15}$ The BBC's PAB records for TOTP do not use the term 'promo' (much less 'video' of course). But they do identify filmed inserts (usually pre-recorded on Ampex tape) and differentiate these from 'stock footage', 'BBC specially filmed inserts', and 'films from other sources'. The Ampex inserts were frequently recorded in studios prior to the show and were usually mimed performances designed to appear on television diegetic with the broadcast. Each of the other categories manifested some degree of greater creativity, be they from existing newsreel footage, library footage, wild footage, or some kind of performance or conceptual film (or animation) made specially to accompany the specific sound recording. Seaton with Down (2007) have assembled their TOTP catalogue from a much wider range of sources (private as well as industry), and the result is probably the most comprehensive record of TOTP's playlists in existence. However, their designations for non-studio appearance coverage are less helpful than the BBC's own records. They employ the term 'promo' liberally, but then also ascribe the word 'film' in other cases. So, for example, whilst Alex Murray's promo for the Moody Blues' 'Go Now' is described as a 'specially shot film', Peter Goldmann's specially shot film of The Beatles' 'Strawberry Fields Forever' is labelled as a 'promo'. Worse, perhaps, from a point of view 
of trying to gauge the extent of TOTP's use of extra-studio material, is that they employ the term promo also in a number of cases to describe pre-recorded taped inserts. In drawing on these combined sources I have tried to make two distinctions clear. Figure 4 only includes examples known to be specially made films rather than pre-recorded inserts (whether made by the BBC or third-party producers). And it differentiates between British and non-British artists in an attempt to indicate the scale of imported footage in lieu of overseas artists' appearances.

${ }^{16}$ Stephen Glynn is not alone in identifying the presentation of these particular songs as akin to music video (see Glynn, 2013: 92-3 and 96-7).

17 Jonathan Brocklebank, (2015), 'The Scot who invented the pop video' (interview with Joe McGrath), Scottish Daily Mail, 12 December, p. 40.

${ }_{18}$ Michael Lindsay-Hogg also directed music videos for The Who and the Rolling Stones. The Who's 'Happy Jack', shot on 19 December 1966, was shown on TOTP on 22 December, the day after its chart entry at no. 30. Over the course of the next five weeks the single rose to no. 3. The Rolling Stones' 'Jumpin' Jack Flash' video was shot at Olympic Studios on 28 April 1968, shown on TOTP on 23 May and 6, 20 and 27 June as it rose to No.1, and Beat-Club (on 22 June); Lindsay-Hogg also shot an atmospheric, though little seen, location video for its B-side 'Child Of The Moon', produced by Sandy Lieberson (see Elliott, 2012: 95 and 99).

${ }^{19}$ Posted by Magnus A., Uppsala Sweden, quoting from Subic Bay Freeport Chamber of Commerce News, Peter Goldmann obituary, 1 March 2005, http://forums.stevehoffman.tv/threads/strawberry-fields-forever-pennylane-promo-director-dead.53401/\#post-1075770

${ }^{20}$ Dave Clark, telephone interview with the author, 22 August 2018.

${ }^{21}$ A vigorous campaign by the MU from 1963 onwards, eventually resulted in the IBA and BBC agreeing to a miming ban from August 1966. However, this position was not achieved without a compromise, as reported in the The Musician: 'This does not mean there will be no miming at all. It will still be possible for performers to mime to recordings made specifically for television. This is not an entirely satisfactory practice; but at least one can be sure that the recordings are used only for the intended purpose, and not for a secondary purpose without payment to the recording musicians', MU/1/5, The Musician, August 1966, p.13, Musicians' Union Archive, University of Stirling. The Beatles fell foul of the new restrictions when TOTP refused to screen a music video, directed by Paul McCartney, of a performance of 'Hello Goodbye' filmed (35mm, col.) at (an empty) Saville Theatre, London on 10 November 1967 for the single's UK release on 24 November (see Lewisohn 2000: 272-3).

${ }^{22}$ Television Film Sequence Order no 1105, 29 December 1967, Top of the Pops files, BBC Written Archives, Caversham.

${ }^{23}$ Mailing letter from James Fitzpatrick, The American Film Foundation, 2 August 1967, TOTP files, BBC Written Archives, Caversham, accessed 7 July 2017.

${ }^{24}$ Letter from Jim Fitzpatrick, President of The American Film Foundation, to Stan Roberts, WKBW-TV, 14 July 1967.

${ }^{25}$ Letter from Johnnie Stewart to Jim Fitzpatrick, August 1967.

${ }^{26}$ Letter from Jim Fitzpatrick to Johnnie Stewart, 16 August 1967.

${ }^{27}$ Whitehead later claimed it as 'the first serious, politically committed, intelligent cultural video - which was also selling a song'. Anon (2002), 'Anarchy Killed the Radio Star: Peter Whitehead (interview)', Dazed and Confused, 93 (September 2002), http://s120937152.websitehome.co.uk/pw/html/films.html.

${ }^{28}$ On 23 August 1967. Day-book (1967), Peter Whitehead Archive, De Montfort University.

${ }^{29}$ Goldmann, like Lindsay-Hogg, came to this assignment from television. He had been a director of pop shows on Swedish TV and was recommended to The Beatles by their mutual friend Klaus Voorman, then bassist in Manfred Mann. See Altham (1967), Lewisohn (2000: 242-3) and also Daniels (2006), 'Suburban Pastoral: Strawberry Fields Forever and Sixties Memory', Cultural Geographies, 13 (1): 28-54.

${ }^{30}$ Episode 2 of series 2 of Beat-Club, broadcast on 22 October 1966 and Episode 31 of the second season of Shindig! (broadcast 30 December 1965). See http://www.tv.com/shows/beat-club/show-13-october-22-1966196613/ and http://www.tv.com/shows/shindig/show-82-december-30-1965-uk-clips-including-the-whokinks-hollies-100671/ 


\section{References}

Aeppli, F. (1996), The Rolling Stones: The Ultimate Guide. Bromley, Kent: Recorded Information Services.

Altham, K. (1967), 'Swedish film director Peter Goldmann tells about TV filming with The Beatles', New Musical Express, 18 February, pp. 2 and 16.

Anon. (2002), 'Anarchy Killed the Radio Star: Peter Whitehead' (interview), Dazed and

Confused, 93 (September). http://s120937152.websitehome.co.uk/pw/html/films.html

Auslander, P. (2008), Liveness: Performance in a mediatized culture, London: Routledge.

Austerlitz, S. (2007), Money For Nothing: A History of the Music Video from the Beatles to the White Stripes, New York/London: Continuum.

Bramwell, T. with Kingsland, R. (2005), Magical Mystery Tours: My life with The Beatles, New York: St Martin's Press.

Brocklebank, J. (2015), 'The Scot who invented the pop video' (interview with Joe McGrath), Scottish Daily Mail, 12 December, pp. 40-41. 
Bedford, P. (2017), Interview with the author, Oxfordshire, 3 November.

Cloonan, M. (2016), 'Negotiating needletime: the Musicians' Union, the BBC and the record companies, c. 1920-1990', Social History, 41: 4, pp. 353-374.

Coates, N. (2007), 'Elvis from the waist up and other myths: 1950s music television and the gendering of rock discourse', in R. Beebe and J. Middleton (eds), Medium Cool: Music videos from soundies to cellphones, Durham and London: Duke University Press, pp. 226252.

Coates, N. (2013), 'Excitement is Made, Not Born: Jack Good, Television, and Rock and Roll', Journal of Popular Music Studies, 25: 3, pp. 301-325.

Cotton, B. (2000), Double Bill, London: Fourth Estate.

Crome, J. (2016), Interview with the author, Hampshire, 8 February.

Daniels, S. (2006), 'Suburban Pastoral: Strawberry Fields Forever and Sixties Memory', Cultural Geographies, 13: 1, pp. 28-54.

Donnelly, K. J. (2007), British Film Music and Film Musicals, Basingstoke: Palgrave Macmillan.

Elliott, M. (2012), The Rolling Stones Complete Recording Sessions, 1962-2012, London: Cherry Red Books.

Evans, J. (2017), The Story of Rock and Pop on British Television, London and New York: Omnibus Press.

Frith, S. (1996), Performing Rites: Evaluating Popular Music, Oxford: Oxford University Press.

Frith, S. (2002), 'Look! Hear! The uneasy relationship of music and television', Popular Music, 21: 3, pp. 277-290.

Fryer, P. (1997), “"Everybody's on Top of the Pops”: Popular music on British television, 1960-1985', Popular Music and Society, 21:2, pp. 71-89. 
Glynn, S. (2013), The British Pop Music Film: The Beatles and Beyond, Basingstoke:

Palgrave Macmillan.

Goodwin, A. (1992), Dancing in the Distraction Factory: Music Television and Popular

Culture, Minneapolis: University of Minnesota Press.

Herzog, A. (2007), 'Illustrating Music: The impossible embodiments of the jukebox film', in

R. Beebe and J. Middleton (eds), Medium Cool: Music videos from soundies to cellphones,

Durham and London: Duke University Press, pp. 30-58.

Hill, J. (1991), 'Television and Pop: The case of the 1950s', in J. Corner (ed.), Popular Television in Britain, London: BFI Publishing, pp. 90-107.

Humphries, P. and Blacknell, S. (2014), Top of the Pops: $50^{\text {th }}$ Anniversary, Swansea: McNidder and Grace.

Inglis, I. (ed.) (2010), Popular Music and Television in Britain, Farnham: Ashgate Press. James, D. E. (2017), Rock 'n' Film: Cinema's dance with popular music, Oxford: OUP. Kaplan, E. A. (1987), Rocking Around the Clock: Music Television, Postmodernism and Consumer Culture, New York: Methuen.

Lee Yoong Hon (2013), 'The greatest era of the UK pop music industry: An efficiency perspective', Popular Music History, 8: 3, pp. 289-306.

Lewisohn, M. (2000), The Complete Beatles Chronicle, London: Hamlyn.

Lindelof, A. M. (2007), 'Look! It's Rock'n'roll! How television participated in shaping the visual genre conventions of popular music', Music, Sound and the Moving Image, 1: 2, pp. 141-159.

Lindsay-Hogg, M. (2011), Luck and Circumstance: A Coming of Age in Hollywood, New York, and Points Beyond, New York: Alfred A. Knopf.

Lindsay-Hogg, M. (2015), Interview with the author, BFI London, 30 June.

Loog-Oldham, A. (2011), Rolling Stoned, Gegensatz Press, http://www.gegensatzpress.com/index.html 
Lowy, A. (2010), 'Ready Steady Go! Televisual Pop style and The Careers Of Dusty Springfield, Cilla Black, Sandie Shaw And Lulu', in I. Inglis (ed.), Popular Music and Television in Britain, Farnham: Ashgate Press, pp. 71-84.

Matthews, S. (2016), Psychedelic Celluloid: British pop music in film and TV, 1965-74, Harpenden: Oldcastle Books.

Mundy, J. (1999), Popular Music on Screen: From Hollywood musical to music video, Manchester and New York: Manchester University Press.

Negus, K. (1992), Producing Pop: Culture and conflict in the popular music industry, London: Edward Arnold.

Nice, D. (2015), Interview with the author by phone, 21 December.

Romney, J. and Wootton, A. (eds), (1995), Celluloid Jukebox: Popular music and the movies since the 50s, London: BFI Publishing.

Scott-Irvine, H. (2012), Procol Harum: The Ghosts Of A Whiter Shade of Pale, London: Omnibus Press (Kindle edition).

Seaton, P. with Down, R. (2007), The Kaleidoscope Music and Variety Guide II, Top Pop: 1964-2006, Handsworth Wood: Kaleidoscope Publishing. Simpson, J. (2002), Top of the Pops, 1964-2002: it's still number one!, London: BBC Worldwide.

Singh, V. (2017), Interview with the author, BFI Southbank, London, 7 February. Stern, A. (2017), Interview with the author, Clapham, London, 6 July. Wharton, A. and Wharton, R. (2016), "THE MAKING OF THE GO NOW PROMO ON 35mm B/W FILM" (Working title). Unpublished memoir.

Witts, R. (2012), 'Needle Time: the BBC, the Musicians' Union, popular music, and the reform of radio in the 1960s', Popular Music History, 7: 3, pp. 241-262. 
Wollen, P. (1986), 'Ways of thinking about music video (and post-modernism)', Critical Quarterly, 28: 1, pp. 167-70. 